UDC 338.45

JEL Classification: M51, M14

DOI: 10.15587/2312-8372.2019.180622

\title{
Hatylo V. \\ DEVELOPMENT OF A METHOD FOR FORMING A POSITIVE IMAGE OF COMPANIES IN THE LABOR MARKET OF UKRAINE
}

Об'єктом дослідження є процес формування іміджевої політики підприємств на ринку праці України. Одним з найбільш проблемних місць дослідження є теоретичне обгрунтування та розробка організачійно-методичних рекомендацій щодо процесу формування іміджевої політики підприємства на ринку праці для залучення потенційних працівників.

Проведений огляд публікаиій, присвячених особливостям формування іміджевої політики підприємств в Україні показав, що для успішного вирішення завдання цілеспрямованого формування позитивного іміджу підприємства на ринку пращі України необхідні:

- ретельний аналіз зовнішніх і внутрішніх умов діяльності підприємства;

- розробка иілей формування іміджу та обгрунтування шляхів і засобів їх досягнення.

Запропоновано методичний підхід до формування позитивного іміджу підприємства на ринку пращі у вигляді послідовності етапів і сукупності методів. Відмінність від відомих схем процесу формування іміджевої політики - відображення в формуванні іміджевої політики постійності та безперервності цього прочесу. Довготривале забезпечення організачії людськими ресурсами є одним з перспективних завдань для сучасного підприємства, особливо при дефіщиті висококваліфікованих кадрів на ринку праці. Виділено принципи формування внутрішнього іміджу: принцип конгруентності, принцип єдиноначальності й стандартизації, принщип відповідності.

Для моделювання процесу формування позитивного іміджу запропоновано модель формування іміджу підприємства на ринку пращі. Наведено базові елементи формування іміджевої політики підприємства на ринку праці для різних етапів співробітництва з корпорацією. Оцінку результативності формування іміджу на ринку праці пропонується виконувати за чотирма напрямами: аналітичним, виробничим, інформачійним та управлінським.

Подальші дослідження планується проводити в рамках оцінки результативності застосування візуальних та вербальних засобів формування іміджу підприємства, які можуть бути відображені у формі паспорту іміджу підприємства. Паспорт має базуватися на оцінці наявності в кадровій політиці конкретного підприємства базових складових, що формують позитивний або негативний імідж підприємства на ринку пращі.

Ключові слова: імідж-стратегї, формування іміджу підприємства, ринок праиі, позитивний імідж, паспорт іміджу підприємства.

\section{Introduction}

In modern economic conditions, the technology of image formation of various objects is increasingly used in many areas of human activity. The concept of image is actively used in politics, marketing and other sciences related to mass communications. According to the prototype, there are several types of image: personal (image of a politician), subject (image of a product), group image (corporate image, image of a party), etc. [1]. In the direction of understanding the image only as a type of social management, research is usually applied in nature, and questions arise about the manipulative nature of the image and its objectivity. The image can be exclusively manipulative in nature with the corresponding narrow sense of the image as a means of creating a certain image, is desirable. With a broader sense of the image, as an insult, imagine that it has semiotic, figurative, cognitive components, the question of its manipulability is removed.

In the context of globalization, the study of the influence of the image of enterprises on the development of modern society as a whole and the labor market in particular is gaining importance [2]. The labor market is a dynamic system, a complex of social and labor relations regarding the conditions of employment, use and exchange of labor for living resources. This system includes a mechanism of selfrealization, a mechanism of supply and demand and operates on the basis of information about changes in the price of labor (wages) [3]. The use of knowledge and skills in shaping the image of enterprises has become one of the most important criteria for the success of professional activities of specialists in the field of management, advertising, public relations [4]. 
Today, almost every second company in Ukraine is concerned about its image as an employer, because image is one of the most important components of an enterprise's competitiveness, a basic prerequisite for its successful operation [5]. The development of the image of enterprises in the labor market for Ukraine is a new trend, while in other countries it is already an integral part of the company's overall strategy. In such conditions, the need to study the process of forming the image of enterprises on the labor market in Ukrainian companies is becoming especially acute [6].

The image of the organization can be both positive and negative [7]. The basis of a positive image is the credibility of the organization, the corresponding stereotyping of its perception. A negative image is manifested in distrust of the organization and its reputation. As a rule, a positive image of an organization saves its resources, and a negative image significantly increases expenses.

A positive image of an organization depends on such factors [8]:

- quality, financial viability, competitiveness of goods

(services);

- management effectiveness;

- organizational culture and environmental safety;

- duplication of the name of the organization through the media.

Thus, to successfully solve the problem of purposefully forming a positive image of the enterprise on the Ukrainian labor market, it is necessary:

- thorough analysis of the external and internal conditions of the enterprise;

- development of image formation goals and substantiation of ways and means to achieve them. That is, the development of scientific and methodological foundations for the purposeful formation of the image policy of enterprises is objectively necessary.

\section{The object of research and its technological audit}

The object of research is the process of forming the image policy of enterprises in the labor market of Ukraine.

The feasibility of image management activities arises when the company is faced with the problem of realizing its potential in conditions of limited resources. For example, production potential in conditions of limited demands. In the case of image management in the labor market, it is said that it is necessary to meet the labor requirements of an appropriate quantity and qualification in conditions of their shortage. In this case, an additional means of attracting the necessary personnel is the formation of a positive corporate image in the labor market.

Currently, the process of forming the image of the enterprise on the labor market in Ukraine is in conditions of insufficient scientific knowledge. So, one of the most problematic places of research is the theoretical justification and development of organizational and methodological recommendations on the process of forming the image policy of the enterprise on the labor market to attract potential employees. Long-term provision of the organization with human resources is one of the most promising tasks for a modern enterprise, especially when there is a shortage of experienced highly qualified personnel in the labor market.

\section{The aim and objectives of research}

The aim of research is development of methodological and scientific and practical recommendations for the effective formation of the image policy of enterprises in the labor market.

To achieve this aim it is necessary to solve the following objectives:

1. To analyze the modern aspects of the process of forming the image policy of enterprises in the labor market.

2. To describe the methodological approach to the formation of a positive image of the enterprise in the labor market.

\section{Research of existing solutions of the problem}

Image formation is carried out with the aim of making the company not only famous, but also attractive [9], because image is an effective form of notification that can create the kind of perception that the target audience needs to achieve specific goals. The issues of forming the image of companies and their role in activities and business activity are the subject of research by many experts [1,3]. Among scientists, interesting are the studies of the problem of forming a positive image of an enterprise. So, in scientific papers [7, 8] it is noted that the effective formation of a positive image is a prerequisite for the enterprise to achieve sustainable and long-term business success. And in [10] the complex mechanism for creating the image of enterprises is detailed and the main components of the image and its perception by society were described, and the rules for maintaining an effective business image were clearly defined.

Thus, the image of the enterprise acts as one of the tools to achieve the strategic goals of the organization, relating to the main aspects of its activities and focused on the future. However, positive fame does not appear by itself and does not exist by itself. It requires focused systematic work to create a positive image of the enterprise, and in a market economy, a positive image is already a prerequisite for the organization to achieve sustainability and positive business success. The tasks to increase the attractiveness of enterprises as an employer are set by the management of most Ukrainian companies before their HR departments. There are many important factors that must be considered before starting the process of forming the image of an enterprise in the labor market. First of all, the company should become such an organization in which people strive to get a job.

The benefits of a positive image are obvious. Firstly, it gives an effect of significance, that is, an enterprise achieving an appropriate level of resistance to changes in the external environment, namely, it leads to a decrease in sensitivity to changes in the sphere of politics and economics that directly affect any enterprise. Secondly, it increases its competitiveness - protects the company from competitors and strengthens its position. Formed a positive image of the company provides free access to various financial or information resources. For this, it is necessary to clearly distinguish the stages of forming the image of the enterprise on the labor market, the influence of external and internal factors. If necessary, use scientifically sound and proven in practice image-forming technologies [11]. 
An analysis of literary sources shows that researchers consider the process of forming the image of an enterprise as part of a marketing strategy and in most cases associate it with a marketing communication strategy. Certain types of image formation strategies with their characteristics are presented in [12]. The author of this work identifies four types of strategies, such as «unique products», «unique organization», «unique personnel and leader» and «combined». However, with this approach, the complex nature of the strategy is absent, since attention is focused on one of the parties and forms the image of the enterprise.

Among the modern methods of forming the image of an enterprise, scientists distinguish mainly marketing communications, among which are: PR, advertising, personal relationships, sales promotion, sponsorship, corporate identity creation, Internet promotion [13]. These methods are used by modern enterprises without calculating the strategic component. In the process of image formation on the labor market, this may not meet expectations and lead to a decrease in the economic efficiency of the enterprise.

The image of the enterprise is becoming critical in light of the shortage of highly qualified personnel in the labor market. So, in the USA and Europe, ratings of the best employers are regularly published, that is, ratings of the reputation component of companies are created [14]. These ratings encourage manufacturers to improve key performance indicators, improve product quality, and service levels. In the United States, such events at the internal image level are moving into the category of corporate social responsibility (CSR), which is held exclusively at the initiative of the business community itself [15]. In Europe, as a rule, the issue of CSR is regulated by the norms, standards and laws of the respective countries. The Ukrainian image management policy is fundamentally different from the European one, which is illustrated in Table 1 [16].

Table 1

Features of image management of enterprises in Europe and Ukraine

\begin{tabular}{|c|c|c|}
\hline Indicators & European Union & Ukraine \\
\hline $\begin{array}{l}\text { Key stake- } \\
\text { holders in } \\
\text { importance }\end{array}$ & $\begin{array}{l}\text { - Staff; } \\
\text { - Consumers; } \\
\text { - Society; } \\
\text { - Shareholders (owners) }\end{array}$ & $\begin{array}{l}\text { - State; } \\
\text { - Shareholders (owners); } \\
\text { - Staff; } \\
\text { - Consumers }\end{array}$ \\
\hline $\begin{array}{l}\text { Stimulating } \\
\text { factors of } \\
\text { image de- } \\
\text { velopment }\end{array}$ & $\begin{array}{l}\text { - Enterprises themselves; } \\
\text { - Non-profit organizations } \\
\text { and society; } \\
\text { - State }\end{array}$ & $\begin{array}{l}\text { - State; } \\
\text { - Enterprises themselves; } \\
\text { - Local authorities }\end{array}$ \\
\hline $\begin{array}{l}\text { Trends in } \\
\text { implement- } \\
\text { ing CSR }\end{array}$ & $\begin{array}{l}\text { - CSR is initiated by the } \\
\text { business itself; } \\
\text { - CSR standards are well } \\
\text { adapted and widely applied; } \\
\text { - CSR focuses on all stake- } \\
\text { holders }\end{array}$ & $\begin{array}{l}\text { - CSR is at the initial stage; } \\
\text { - Often not understood as a ho- } \\
\text { listic system and its benefits in } \\
\text { the long run are underestimated; } \\
\text { - CSR is mainly oriented to the } \\
\text { state and shareholders, to a les- } \\
\text { ser extent to society }\end{array}$ \\
\hline
\end{tabular}

Review and analysis of literary sources on image management indicate a significant interest in the importance of image for the enterprise and its management concepts [1]. However, most of the modern methods used in the field of work with the image of the organization do not have a sufficient theoretical study. First of all, the question of determining the process of forming the image policy of enterprises on the labor market by scientists is almost not studied and has a fragmentary character [3, 6].
In the process of forming the image strategy of enterprises, despite the potential positive impact of the latest technologies on economic growth, it is important to consider their possible negative impact on the labor market, at least in the short term. Today, new technologies are fundamentally changing the nature of labor in all sectors and professions. Particularly significant changes are currently taking place in the relations between these elements, which are being formed under the influence of the current stage of technological development (the sixth technological order), which gives rise to a new type of industry - Industry 4.0 [17]. New types of economy are emerging [18]:

- information economy;

- innovative economy;

- new economy;

- knowledge economy;

- economy based on knowledge, within the framework of which cardinal changes in the business process model of competitive enterprises are undergoing.

In 2018, the World Economic Forum was held, the purpose of which was to determine the current level of readiness of countries for potential opportunities and challenges that arise under the influence of changes in the external environment, caused by including the transition to «Industry 4.0» [19]. According to the results of this forum, Ukraine belongs to countries that have weak current positions in the formation of image strategies of enterprises in the labor market. So, given the trends of Industry 4.0, many applied issues related to the process of forming the image policy of enterprises in the labor market still require a constructive outcome. They become especially acute in the conditions of the development of market relations and the implementation of structural transformations of the economy and the influence of the image on the labor market on the competitiveness of enterprises. This is due to the fact that an important problem in the conditions of development of market relations and the implementation of structural transformations of the economy is the information interaction of enterprises with the external environment. The progressive direction of solving this problem is the use of modern approaches and management tools in the field of image policy of enterprises.

\section{Methods of research}

The theoretical and methodological basis of the study is the provisions of a general scientific methodology, the principles and laws of construction and analysis of the enterprise image management system, qualitative approaches to improving the process of forming the image of the enterprise on the labor market and its individual elements.

To solve the tasks, the method of logical generalization, the method of generalization of data and comparative comparison are used.

\section{Research results}

A review and analysis of literary and Internet sources show that one of the important directions of the company's activity is the formation of a positive and effective image of the organization on the labor market, and on this basis, the achievement and preservation of its reputation and built trust relationships. So, today the image of the company as an employer is a set of created images and messages about the company as a positive place of work, which are 
transmitted to the labor market in all possible ways [6], that is, the image of the employer in a rather superficial, artificially created way that exists in thoughts person. In addition, the image of a modern employer may not reflect the real characteristics of the conditions of employment in the company, rather reflects the emotional judgment of «like it, don't like it» and is made without direct experience of interaction with the company employer.

The formation of the image policy of the enterprise on the labor market is a focused activity to create a positive image of the enterprise, includes all the components of managing the image of the enterprise on the labor market [2]. The problem of forming an organization's image policy on the labor market is still not well understood, therefore, the development of a methodological approach to creating a positive image of an enterprise in the labor market is important. Based on the research, let's determine the main stages of the methodological approach to the formation of a positive image of the enterprise in the labor market (Fig. 1):

- research and monitoring of factors in the formation of the image of the enterprise on the labor market;

- preparation of the concept of image policy of the enterprise in the labor market;

- development of image policy of the enterprise;

- assessment of the effectiveness of the image policy

of the enterprise in the labor market.

The difference from the well-known schemes of the image policy formation process, that is, the determination of the influence of specific external and internal factors on the image of the enterprise on the labor market, is reflected in the formation of the image policy of the constancy and continuity of this process.

Stage of research and monitoring of factors in the formation of the image of the enterprise in the labor market. When forming the image policy of enterprises, a number of factors must be taken into account that influences the formation of the image of the employing organization. The study allows to summarize the main factors that are important for the employee when choosing an enterprise, and which form the image of the enterprise on the labor market (Fig. 2).

Consideration of these factors is a prerequisite for the formation of the image of the enterprise on the labor market in modern conditions. In a further study, it is precisely on these factors that the image policy should be based, and recommendations for its development in the enterprises under study.

Stage of preparation of the concept of image policy of the enterprise in the labor market. At this stage, it is necessary to understand what the company's image on the labor market, the values the company wants to convey to your team and to your environment, which includes candidates, customers, partners, competitors.

The process of forming the image of the enterprise on the labor market goes in two ways: natural and purposeful [1]. The natural formation of the image of the organization includes all subsystems of the social environment of the organization, information flows from which are poorly controlled by the organization's management. The purposeful formation of the internal image includes visual, verbal, situational and conceptual constructs.

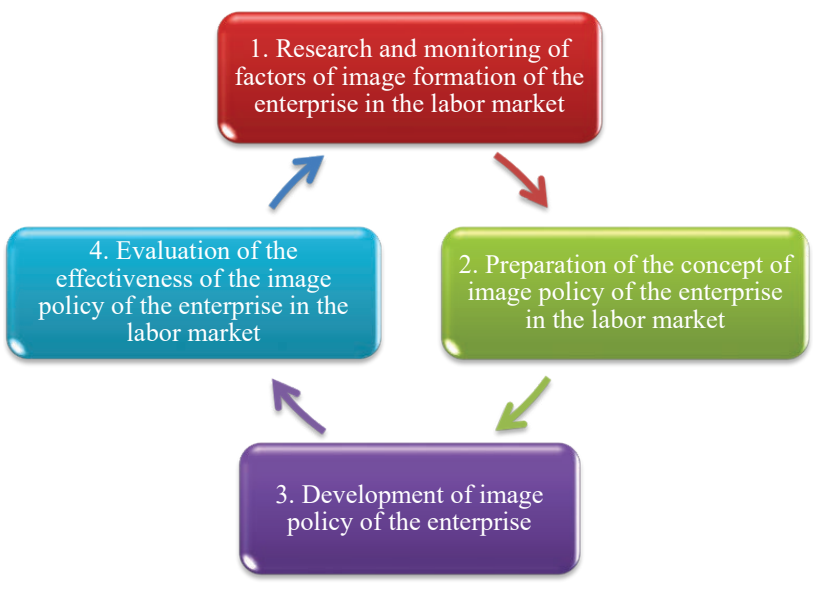

Fig. 1. The main stages of the methodological approach to the formation of a positive image of the enterprise on the labor market

Factors of forming a positive image of an enterprise in the labor market

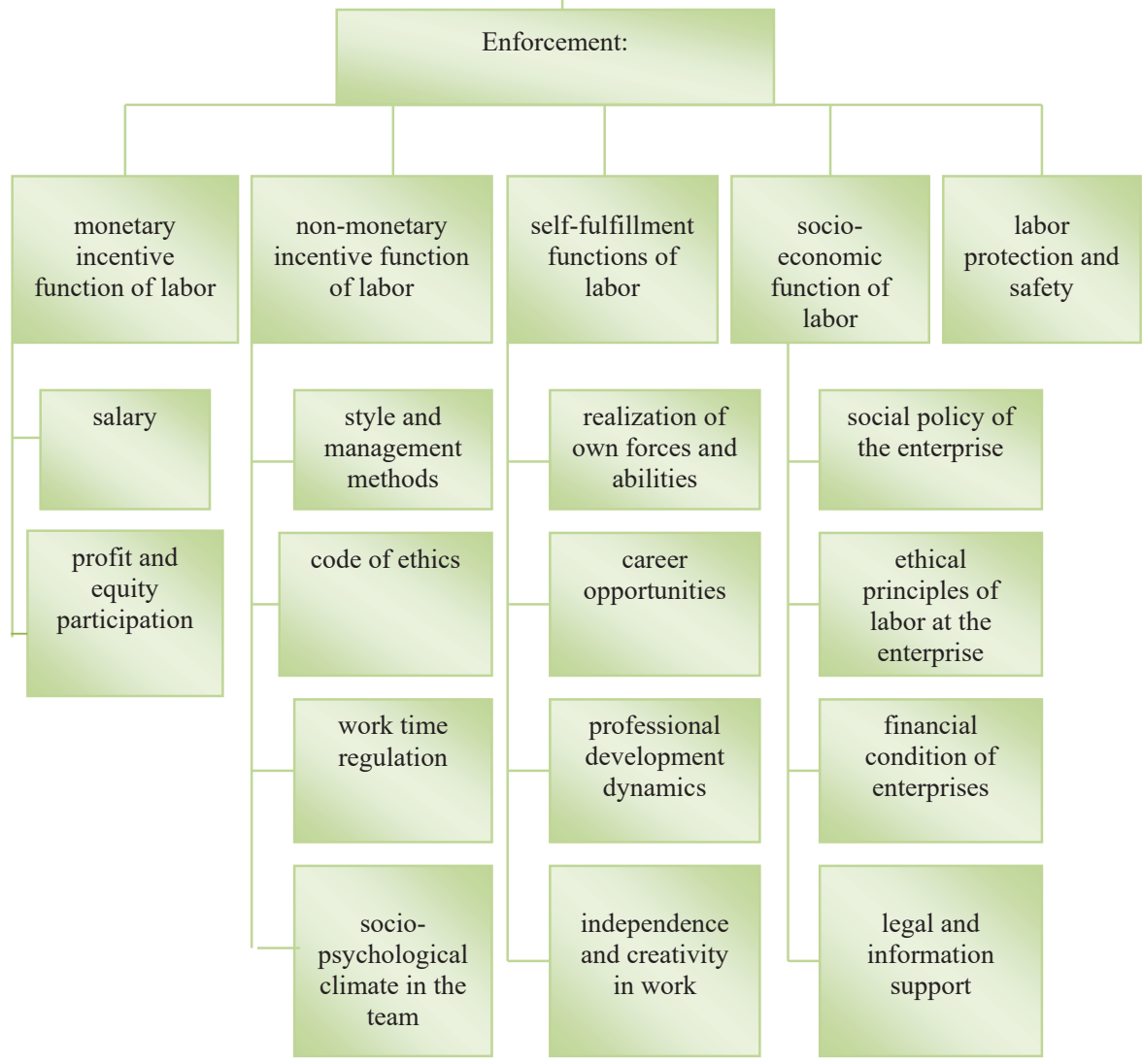

Fig. 2. Factors for the formation of a positive image of the enterprise in the labor market 
For the formation of an effective image policy of the enterprise, targeted formation of the image on the labor market is chosen, since here information flows are initiated and controlled by management.

The purposeful image-building process is a process of social perception; mediated by visual, verbal, situational and conceptual constructs based on communication channels.

Let's single out the following principles for creating an internal image:

- congruency principle - the image is formed holistic, reflecting both positive and negative properties of the organization, not contradicting each other;

- principle of unity of command and standardization - a strong image is formed through coordinated actions based on a single concept;
- compliance principle - the image is formed in accordance with the expectations, values of employees, prevailing stereotypes, organizational culture.

When forming the concept of image policy of an enterprise in the labor market, one should also take into account the relationship with labor functions (Fig. 3).

Stage of development of image policy. A positive image of an enterprise is formed according to a concept based on the results of research and monitoring of factors that shape the image of an enterprise in the labor market. Development of image policy includes the preparation of the previous working group on middle managers, participation in the work of the working group, the consistent implementation of planned activities and the implementation of feedback. Selection of key channels and promotion strategies. Definition of communication policy in the labor market.

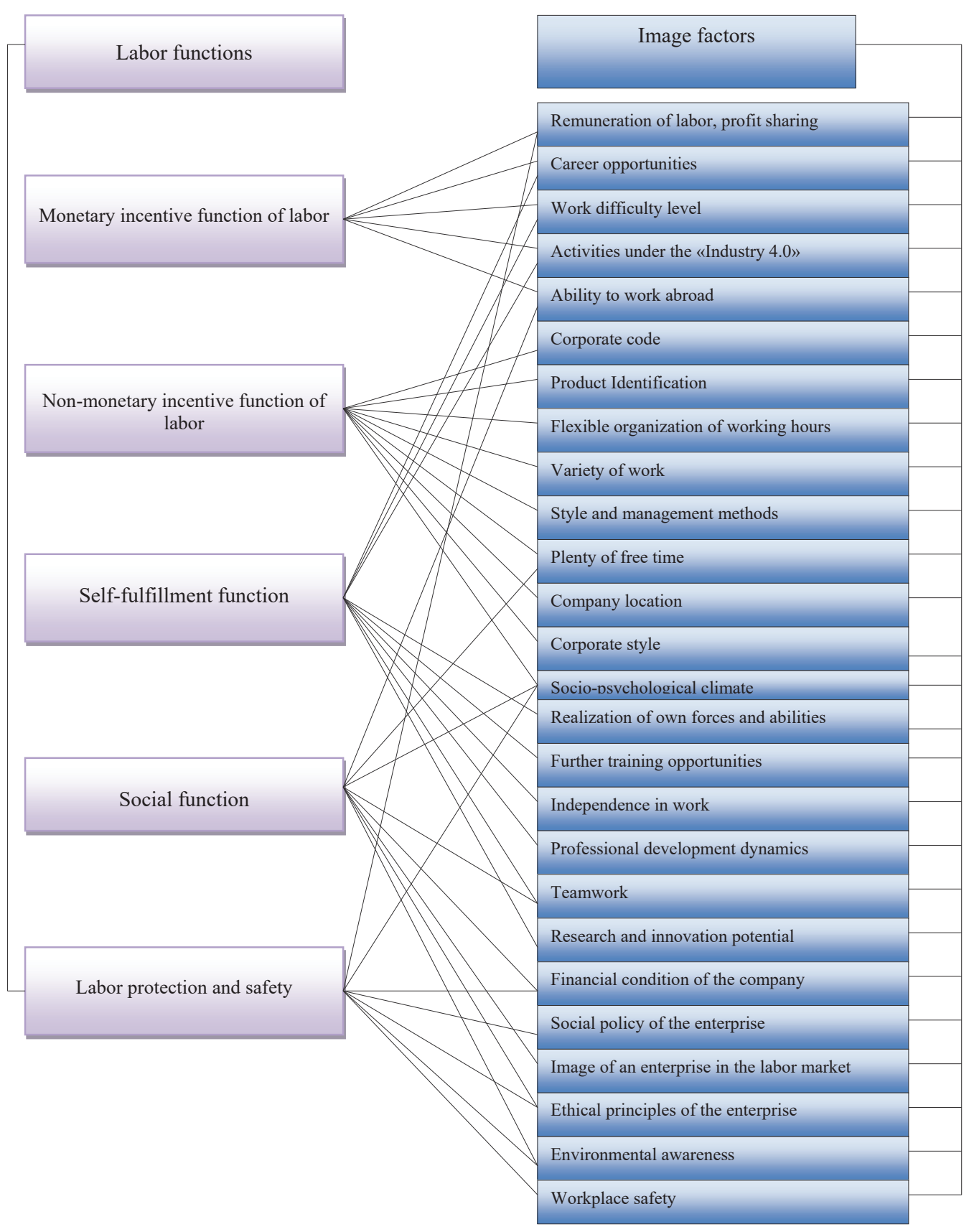

Fig. 3. The relationship of the image of the employer with the functions of labor (compiled on the basis of [16, 17]) 

image, a model for forming the image of an enterprise on the labor market is proposed. The basic elements of this model at various stages of cooperation with the employee are shown in Fig. 4.

The model illustrates that at the stage of acquaintance with the corporation, the most significant factors in the image are material components, namely: remuneration and social standards. It should be noted that already with the extension of cooperation, psychological factors and the satisfaction of workers with labor standards come to

At the stage of forming partnerships, when loyalty to the company is formed, there is a change in motivation factors, which in turn should be taken into account in the process of shaping image policy in the labor market under new employees.
At this stage, to model the process of forming a positive the first level.

Creating an attractive image of an enterprise in the labor market requires significant investment in the long run. The next step towards a positive image of the enterprise in the labor market is the implementation of the strategy. To achieve a better result, adjustments may be made to it.

Stage of evaluating the effectiveness of the image policy of the enterprise in the labor market. Assessing the effectiveness of the enterprise in terms of creating a favorable image on the labor market should take into account the features of the functioning of the entire personnel system of the enterprise. According to the State Statistics Service of Ukraine [20], personnel management costs do not exceed $2.5-4 \%$ of the operating budget of the enterprise. The indicators of the effectiveness of the personnel management system also include parameters that determine the effectiveness of image formation in the labor market.

It is proposed to evaluate the

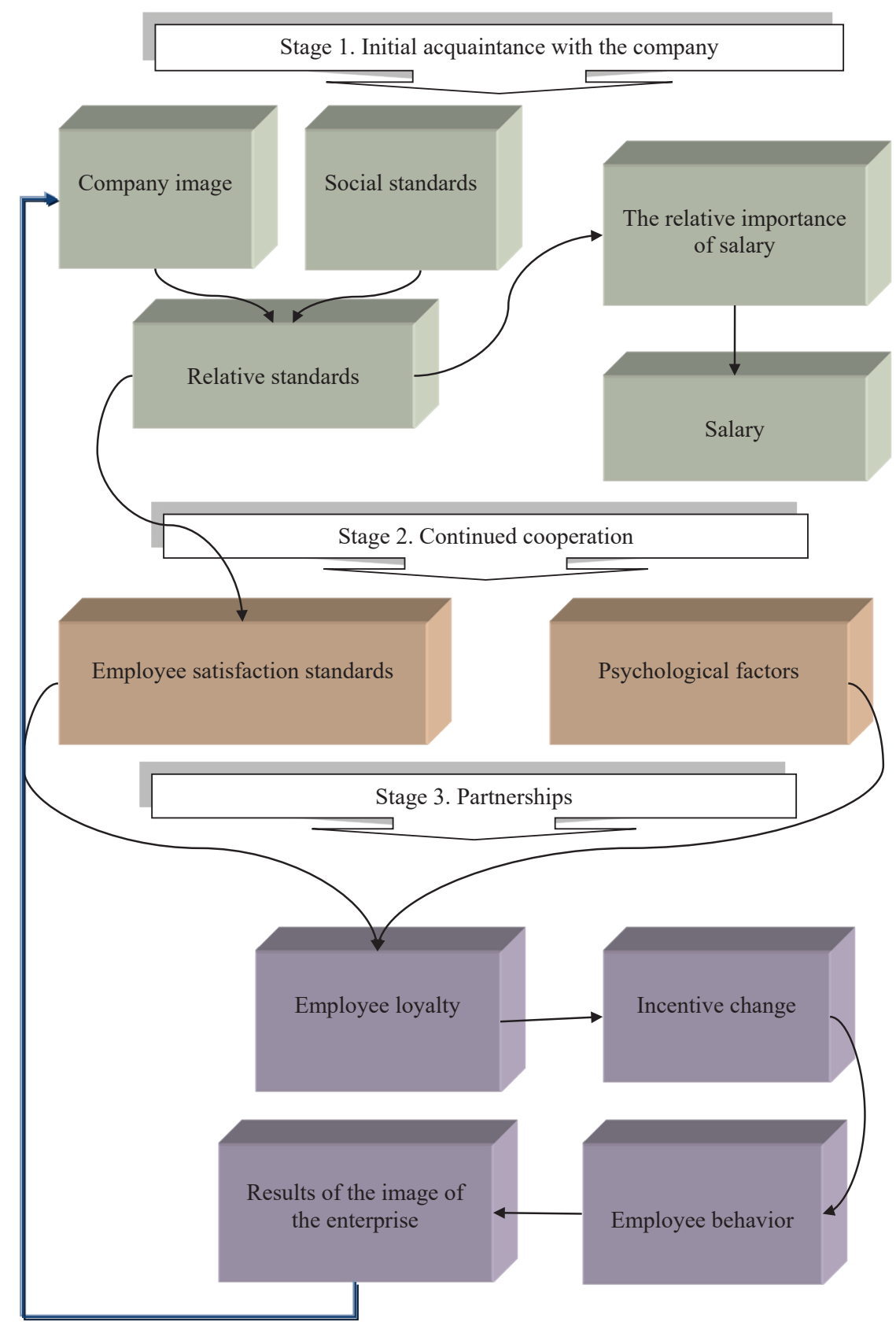

Fig. 4. The basic elements of the model of forming the image of the enterprise on the labor market at various stages of cooperation with the employee effectiveness of image formation in the labor market in four areas: analytical, production, information and management. To the indicators of the analytical group offers to make the following:

- coefficient of specialized staff units;

- coefficient of the number of specialized workers;

- coefficient of specific gravity of specialists whose qualitative characteristics correspond to the requirements of the enterprise;

- turnover rate coefficient;

- coefficient of economic attractiveness of labor at the enterprise - competitive coefficient reflecting the number of applicants for vacant positions.

To the indicators of the production group let's offer include:

- coefficient of the availability of personnel reserve;

- coefficient of effectiveness of endogenous selection of personnel for vacant positions;

- coefficient of exogenous admission of workers to vacant places; - effectiveness of meeting staffing needs;

- reaction time to the first interview;

- time from the decision to accept the employee to the beginning of his work.

As an indicator of information efficiency of work on image formation in the labor market, the effectiveness of various advertising sources should be used.

The managerial effectiveness of image formation in the labor market is assessed based on a number of indicators. They characterize the professional level, the competence 
of specialists, the distribution of powers in the personnel management system for the implementation of measures to form the image and improve the functional relationships of the enterprise and the labor market. The following parameters can be made to this group: coefficient of functional-technological documents operating indicator of labor intensity, level of use of working time.

Also, this group of indicators includes indicators of the level of responsiveness of the image management subsystem (the normative period for completing a task, reaction time to changes in the external environment, the degree of division of labor into marketing subsystems).

Performance indicators allow to assess the effectiveness of the sources of satisfaction of personnel requirements by comparing the specific gravity of each source in the personnel structure of the enterprise and the financial costs associated with the use of each of the sources. This allows to conclude about the quality of the process of formation of personnel by the enterprise.

Information performance is evaluated on the basis of the cost of creating an image through advertising. In this case, the company should strive to achieve the ratio of «minimum cost - maximum reaction to advertising». This condition is gaining importance in conditions of an increase in the personnel selection coefficient.

Thus, the process of forming the image of the enterprise in the labor market plays an important role. Despite this, it is necessary to devote more time and financial resources to enterprises to create and maintain a positive image on the labor market, which gives a number of advantages:

- stable financial performance;

- increase the level of trust and loyalty;

- increase the level of competitiveness in the labor market.

\section{SWOT analysis of research results}

Strengths. The proposed methodological approach to the formation of a positive image of an enterprise in the labor market will provide a detailed picture of the state of image policy. The results will be used as the basis for the further implementation of the image strategy as part of the enterprise development strategy.

Weaknesses. The analysis of modern aspects of the process of forming the image of an enterprise on the labor market in Ukraine showed that an important problem in the development of market relations and the implementation of structural transformations of the economy is the information interaction of enterprises with the external environment. In addition, in the framework of managing the organizational behavior of employees, the methodological and practical application of the organizational and cultural approach is underdeveloped.

Opportunities. Further research is planned to be carried out as part of the assessment of the effectiveness of the use of visual and verbal means of forming the image of the enterprise, which can be reflected in the form of a passport of the image of the enterprise. The passport should be based on an assessment of the presence in the personnel policy of a particular enterprise of basic components that form a positive or negative image of the enterprise in the labor market.
Threats. A number of environmental factors have a negative impact on the object of study:

- demographic crisis (employers will fight for a slowly growing working class or even one that is shrinking, so in the process of creating an image on the labor market it will be necessary to focus on the factors that encourage people to increase wages);

- political situation in the country (the difficult economic, political and military situation in the country caused a serious crisis in the labor market. Many companies took a wait-and-see attitude in the process of forming an image strategy that affects the competitiveness of the enterprise as a whole);

- changing labor legislation (new labor relations require the development of a new image policy of the enterprise on the labor market to provide highly qualified personnel in compliance with labor legislation).

\section{Conclusions}

1. The analysis of publications devoted to the study of the process of forming the image strategy of enterprises in the labor market shows that a large number of applied issues related to the process of forming the image policy of enterprises in the labor market still require a constructive outcome. A progressive direction in solving this problem is the use of modern approaches and the latest management tools in the field of image policy of enterprises.

2. A methodological approach to the formation of the image of the enterprise on the labor market is proposed and its main stages are determined. The basic elements of forming the image policy of the enterprise on the labor market for the various stages of cooperation with the corporation are given. It is proposed that performance assessment of image formation on the labor market be carried out in four areas: analytical, production, information and management. The indicators for assessing the effectiveness of image formation in the labor market for each of the proposed areas are presented. The developed recommendations will allow managers to build practical work to increase the attractiveness of their organizations in the labor market, which will result in the acquisition of competitive advantages in attracting potential employees.

\section{References}

1. Sharkov, F. I. (2006). Imidzh firmy: tekhnologiia. Moscow: Akademicheskii proekt, 271.

2. Sohnen, E. (2018). Key Approaches to Labor Market Assessment. Report, USAID. Washington, 64.

3. Shavkun, I. H. (2016). Formuvannia imidzhu orhanizatsii. Zaporizhzhia: ZNU, 111.

4. White, S. (2018). Creating better business environments for micro and small enterprises. Technical Report, Donor Committee for Enterprise Development. Cambridge, 55.

5. Lozovsky, O. M., Dronchak, I. V. (2016). Formation of the company image as an element of competitiveness. Young scientist, 1 (1), 101-104.

6. Soroka, O. V. (2016). HR-brand: essence and state in Ukraine. Economics and organization of management, 3 (23), 293-301. Available at: http://jeou.donnu.edu.ua/article/view/2898

7. Yasinskaya, Y. R. (2015). The image of the company: definition, structure, features of formation. Bulletin of the Lviv Commercial Academy. The series is economical, 48, 98-103. Available at: http://nbuv.gov.ua/UJRN/Vlca_ekon_2015_48_19

8. Orban-Lembryk, L. E. (2003). Psykholohiia upravlinnia. Kyiv: Akademvydav, 568 
9. Balichova, V. O., Tyukhtenko, O. O. (2014). Methodological aspects of the evaluation of the image of tourism enterprises. Bulletin of Khmelnitsky National University, 2 (5), 160-162.

10. Ji, B. (2000). Company image. Planning, formation, promotion. Saint-Petersburg: Peter, 224.

11. Semenchuk, T. B., Basarab, N. A. (2016). The formation of company image. Economy and Society, 7, 473-477.

12. Fedorov, V. A. (2017). Classification of strategies formation of the image of the enterprise. Economics and Society, 9, 668-672.

13. Rogaleva, N. L. (2007). Sovremennaia koncepciia imidzha organizacii. Upravlenie personalom, 2. Available at: https://www. lawmix.ru/bux/74322

14. Dzhonson, M. (2004). Bitva za personal. Moscow: Piter, 107.

15. Illiashenko, S. M., Kolodka, A. V. (2016). Rol imidzhu u zabezpechenni staloho rozvytku promyslovykh pidpryiemstv. Stalyi rozvytok - XXI stolittia: upravlinnia, tekhnolohii, modeli. Dyskusii 2016. Cherkasy: Chebanenko Yu., 522-535.

16. Odintseva, S. V. (2018). Formation of Enterprise Image: Global and Domestic Experience. Actual problems of economics and management, 12. Available at: http://ela.kpi.ua/handle/ $123456789 / 24621$

17. Rüßmann, M., Lorenz, M., Gerbert, P., Waldner, M., Justus, J., Engel, P., Harnisch, M. (2015). Industry 4.0. The Future of Productivity and Growth in Manufacturing Industries. Boston Consulting Group, 20.

18. Svetlichnaya, V. L. (2015). Theoretical base of new paradigm of society are economies of knowledge. Economics: time realities, 3 (19), 184-193. Available at: http://economics.opu.ua/ files/archive/2015/No3/184-193.pdf

19. Readiness for the Future of Production Report 2018. Insight Report (2018). World Economic Forum. Available at: http:// www3.weforum.org/docs/FOP Readiness Report 2018.pdf

20. Derzhavna sluzhba statystyky Ukrainy. Available at: http:// www.ukrstat.gov.ua

Hatylo Valentina, Senior Lecturer, Department of Management, $\mathrm{Na}$ tional Aerospace University «Kharkiv Aviation Institute», Ukraine, e-mail:gatulo@ukr.net, ORCID:http://orcid.org/0000-0002-5518-9694 